\title{
Study of morphological types of anemia in pregnant women with low socioeconomic status attending antenatal care at rural tertiary care hospital
}

\author{
Patil JD. ${ }^{1}$, Nagare MR. ${ }^{2}$ \\ DOI: https://doi.org/10.17511/jopm.2020.i03.07
}

1 Jayraj Devidas Patil, Undergraduate student, MIMER Medical College, Pune, Maharashtra, India. https://orcid.org/0000-0002-5448-4472

3* Mangala Rajesh Nagare, Assistant Professor, Department of Pathology, MIMER Medical College, Pune, Maharashtra, India. https://orcid.org/0000-0001-7107-5120

Introduction: Anemia is a major public health problem affecting both the developed(14\%) as well as the developing $(51 \%)$ countries. India became the first developing country to take up a National Nutritional Anemia Prophylaxis Program (NNAPP) to prevent anemia among pregnant women. Aims and objectives: 1.To find out the prevalence of anemia in ANC patients with low socioeconomic status2. To find out morphological types of anemia in this ANC patients 3.To study the various factors causing anemia in this group. Material and Methods: The type of this study is the CrossSectional Study, it was conducted on the ANC patients attending OPD and IPD of OBGY department at BhausahebSardesai Talegaon Rural Hospital, Maharashtra.The written consent of the pregnant women was obtained prior to the collection of the blood sample. Results: In the present study prevalence of anemia was found to be $72.58 \% .15 .32 \%$ of women found to be mildly anemic, $52.42 \%$ moderately anemic and $4.84 \%$ severely anemic followed by $27.42 \%$ not anemic. Conclusion: Microcytic hypochromic blood picture is predominant in the present study, it indicates there are deficient iron intake and lack of awareness about proper diet. Proper interaction, information, medication, proper diet containing all nutrients, cooking in iron utensils, fortification of food and salt with iron and birth control for proper spacing of pregnancies; such measures will go long way in improving maternal and fetal outcome.

Keywords: Anemia, Low socioeconomic group, Morphological types of anemia, Pregnant women, Prevalence

Corresponding Author

Mangala Rajesh Nagare, Assistant Professor, Department of Pathology, MIMER Medical College, Pune, Maharashtra, India.

Email: mangalnagare@yahoo.co.in
How to Cite this Article

To Browse

Patil JD, Nagare MR. Study of morphological types of anemia in pregnant women with low socioeconomic status attending antenatal care at rural tertiary care hospital. Trop J Pathol Microbiol. 2020;6(3):253-260. Available From https://pathology.medresearch.in/index.php/jopm/ar ticle/view/433

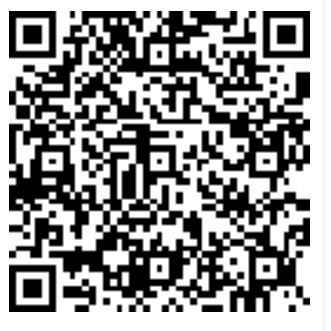

Manuscript Received 05-03-2020

Conflict of Interest No

Review Round 1
$16-03-2020$
Funding
Nil

and 2020 by Jayraj Devidas Patil, Mangala Rajesh Nagare, Mangala Rajesh Nagare and Published by Siddharth Health Research and Social Welfare Society. This is an Open Access article licensed under a Creative Commons Attribution 4.0 International License https://creativecommons.org/licenses/by/4.0/ unported [CC BY 4.0]

\author{
Review Round 2 \\ 22-03-2020 \\ Ethical Approval \\ Yes
}

Accepted 28-03-2020

Note 


\section{Introduction}

Anemia is a major public health problem affecting both the developed as well as developing countries. According to the World Health Organization, the prevalence of anemia among pregnant women in developed countries is about $14 \%$, whereas it is still as high as $51 \%$ in the developing world [1].

Anemia refers to a condition in which the hemoglobin contentof the blood is lower than normal for a person's age, gender, andenvironment, resulting in the oxygen-carrying capacity of the bloodbeing reduced[2].

India became the first developing country to take up a National Nutritional Anemia Prophylaxis Program (NNAPP) to prevent anemia among pregnant women. NNAPP was initiated in 1970 during the fourth 5-year health plan with the aim of reducing the prevalence of anemia to $25 \%[1,3,5,6]$.

Anemia is known to be associated with multiple factors, but in the pregnant women, the common factors include - Poor socioeconomic status, high parity, short birth interval, poor diet both in quantity and quality, lack of health and nutrition awareness, and a high rate of infectious diseases[7].

The mean minimum acceptable hemoglobin level during pregnancy by WHO criteria are taken to be $11.0 \mathrm{~g} / \mathrm{dL}$. WHO and ICMR (Indian Council of Medical Research) further divides anemia in pregnancy into: mild anemia (hemoglobin 10-10.9 $\mathrm{g} / \mathrm{dL}$ ), moderate anemia (hemoglobin7.0-9.9 g/dL) and severe anemia (hemoglobin $<7 \mathrm{~g} / \mathrm{dL}$ ) $[2,4,6,8,9]$.

While malnutrition is prevailing among all segments of the population, poor nutrition among women begins in the early years and continues during their lifetime. Usually, female members of the family are last to eat. Consequently, if there is not enough food they are the ones to suffer mainly.

Unequal access to food, heavy work demands, nutritional deficiencies including iron, makes Indian women susceptible to illness, and anemia. Low intake of ascorbic acid and meat due to low income reduces the absorption of iron $[10,11]$.

It is not enough to just report that patient has anemia, morphological subtyping of anemia is also equally required so that the clinician can be properly guided for the proper management and follow up of the patient. Morphologically, in peripheral blood
Smear examination, anemia can be microcytic hypochromic type, macrocytic type, dimorphic type, and normocytic normochromic type. Each of these morphological types has varied etiologies and can be known by correlating with the patient's clinical history, clinical examination, and by further suitable investigations[12].

Hence the present study will be carried out with objectives to study the prevalence of anemia among rural pregnant women and to find out the morphological type of anemia as well as to study the various factors causing anemia among these patients.

\section{Aims and Objectives}

1. To find out the prevalence of anemia in ANC patients with low socioeconomic status.

2. To find out morphological types of anemia in these ANC patients.

3. To study the various factors causing anemia in this group.

\section{Material and Methods}

\section{Study Design: Cross-Sectional study}

Study period: 2 months (conducted in the month of 5 May 2018 - 5 July 2018)

This study was conducted on the ANC patients attending OPD and IPD of the OBGY department at BhausahebSardesai Talegaon Rural Hospital, Maharashtra,India. The written consent of the pregnant women was obtained prior to the collection of the blood sample. Data was collected with the help of proforma. A blood sample was collected in the anticoagulant bulb. The diagnosis of anemia done by $\mathrm{Hb}$ estimation and estimation of blood indices. Morphological typing is done with the help of Peripheral blood smear stained with Leishman stain.

Sample size:Prevalence of anemia in previous studies was 60\%[1]. Considering allowable error $15 \%$ of prevalence and $95 \%$ confidence interval $($ alpha $=0.05)$.

Formula used for sample size is,

$N=(\mathrm{z}) 2 \mathrm{pq} /(\mathrm{I}) 2$

Where, $\mathrm{n}=$ sample size

$Z=$ level of significance 
$\mathrm{P}=$ positive prevalence

$\mathrm{Q}=$ non- prevalence

$\mathrm{L}=$ allowable error

$$
N=(1.96 \times 1.96) \times 60 \times 40
$$

$$
9 \times 9
$$

$$
=113
$$

Considering $10 \%$ drop out rate total sample size $=113+11=124$

J) Selection Criteria: Type of sample will be purposive.Consecutive 124 ANC patients coming to the OBGY OPD and IPD at BhausahebSardesai Talegaon Rural Hospital Maharashtra, satisfying inclusion and exclusion criteria.

Inclusion criteria: ANC patients with low socioeconomic status having an orange or yellow ration card/below the poverty line. Based on the occupation of the head of the family, education of the head of the family and total monthly income of the family; socioeconomic classes can be classified as follows according to Modified Kuppuswamy socioeconomic scale,

Table-1 Kuppuswamysocioeconomic status scale.

\begin{tabular}{|l|l|}
\hline \multicolumn{1}{|c|}{ Total score } & \multicolumn{1}{c|}{ Socioeconomic class } \\
\hline $26-29$ & Upper (I) \\
\hline $16-25$ & Upper middle(II) \\
\hline $11-15$ & Lower middle(III) \\
\hline $5-10$ & Upper lower(IV) \\
\hline$<5$ & Lower(V) \\
\hline
\end{tabular}

Women belonging to lower socioeconomic classes were included.

Exclusion criteria: ANC patients with other complications related to pregnancy, obesity, diabetes, multiple pregnancies.

Data was collected using a prepared proforma sheet which was to be filled. Which includes biodata of patient, her obstetric history, personal history including dietary habits, treatment history, past history, family history, and investigations to be performed.

Sample collection: $2 \mathrm{ml}$ blood in EDTA vacutainer for $\mathrm{Hb}$ estimation, estimation of blood indices, and PBS examination.

Statistical Analysis: Statistical analysis will be
Done with appropriate tests in consultation with a statistician

H) Risks involved: No major risk involved, hematoma formation, or dizziness following sample collection may occur.

Ethical clearance: Ethical clearance was obtained from the Institutional ethics committee, and the procedures are followed in accordance with the ethical standards of this ethical committee.

\section{Results}

\section{Study Design}

The present study was carried out in a rural tertiary care hospital over a period of 2 months, out of 124 , in which 90 were anemic showing the prevalence of $72.58 \%$.

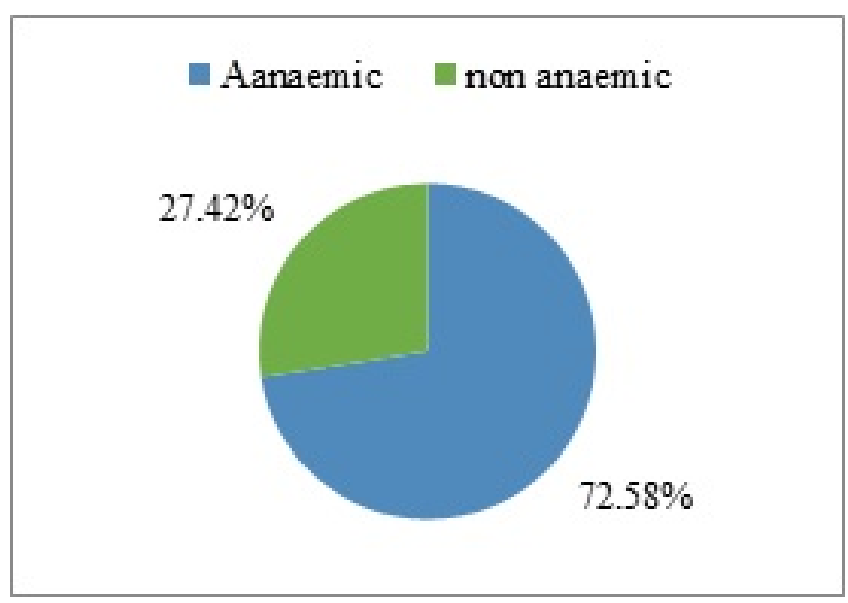

Fig-1: Prevalence of anemia.

Table-2: Summary of hematological parameters of Anemic women.

\begin{tabular}{|l|l|l|l|}
\hline \multicolumn{1}{|c|}{$\begin{array}{c}\text { Hematological } \\
\text { Parameters }\end{array}$} & \multicolumn{1}{|c|}{$\begin{array}{c}\text { Mean } \\
\text { values }\end{array}$} & \multicolumn{1}{|c|}{$\begin{array}{c}\text { Standard } \\
\text { Deviation }\end{array}$} & \multicolumn{1}{|c|}{$\begin{array}{c}\text { vormal } \\
\text { values }\end{array}$} \\
\hline $\mathrm{Hb}(\mathrm{gm} / \mathrm{dl})$ & 9.01 & 1.89 & 11 \\
\hline $\mathrm{MCV}(\mathrm{fl})$ & 71.28 & 11.21 & $80-96$ \\
\hline $\mathrm{MCH}(\mathrm{pg})$ & 23.21 & 3.81 & $27-33$ \\
\hline MCHC (\%) & 32.00 & 2.13 & $33-36$ \\
\hline PCV (\%) & 28.17 & 3.56 & 37 \\
\hline RDW-CV (\%) & 15.46 & 3.63 & $11.6-14.6$ \\
\hline
\end{tabular}

The above table summarizes mean values, standard deviation, and the normal value of the parameters viz. $\mathrm{Hb}, \mathrm{MCV}, \mathrm{MCH}, \mathrm{MCHC}, \mathrm{PCV}$, and RDW-CV (Red cell distribution width coefficient of variation). According to table no:2 mean values of hemoglobin (9.01 g/dl), MCV (71.28 fl ), PCV (28.17\%) are below their normal values and mean value of RDW$\mathrm{CV}$ is $15.46 \%$. 
Table-3: Grading of anemia amongst study subjects.

\begin{tabular}{|l|l|l|}
\hline \multicolumn{1}{|c|}{ Hb concentration $(\mathrm{g} / \mathrm{dl})$} & No. of women & Percentage \% \\
\hline Mildly Anemic $(10-10.9)$ & 19 & 15.32 \\
\hline Moderately Anemic $(7-9.9)$ & 65 & 52.42 \\
\hline Severely Anemic $(<7)$ & 6 & 4.84 \\
\hline Not Anemic $(>11)$ & 34 & 27.42 \\
\hline Total & 124 & 100 \\
\hline
\end{tabular}

$52.42 \%$ of women were found to be moderately anemic followed by $27.42 \%$ not anemic, $15.32 \%$ mildly anemic and $4.84 \%$ severely anemic.

Table-4: Morphological subtypes of anemia.

\begin{tabular}{|l|l|l|}
\hline \multicolumn{1}{|c|}{ Morphology of RBC } & No. of smears & Percentage $\%$ \\
\hline Microcytic hypochromic & 67 & 74.44 \\
\hline Microcytic normochromic & 3 & 3.33 \\
\hline Normocytic normochromic & 18 & 20 \\
\hline Normocytic hypochromic & 2 & 2.22 \\
\hline
\end{tabular}

PBS examination of anemic women shows microcytic hypochromic anemia (74.44\%), microcytic normochromic (3.33\%), normocytic normochromic (20\%), and normocytic hypochromic (2.22\%).

Table-5: Age-wise distribution of grading of anemia.

\begin{tabular}{|l|l|l|l|l|l|}
\hline Agein years & Mild & Moderate & Severe & Total & Percentage\% \\
\hline$\leq 20$ & 4 & 8 & 1 & 13 & 14.44 \\
\hline $21-25$ & 5 & 36 & 1 & 42 & 46.67 \\
\hline $26-30$ & 10 & 14 & 2 & 26 & 28.89 \\
\hline$\geq 31$ & - & 7 & 2 & 9 & 10 \\
\hline
\end{tabular}

Anemia is most commonly found in the age group $21-25(46.67 \%)$ and It was least commonly found in the age group $\geq 31$ year.

Table-6: Factors associated with anemia in pregnancy.

\begin{tabular}{|l|l|l|l|l|} 
Factor & Anemia present & No Anemia & $\mathrm{X}^{2}$ - value & p-value \\
\hline
\end{tabular}

\section{Age (in years)}

\begin{tabular}{|l|l|l|l|l|}
\hline$\leq 20$ & $13(72.22 \%)$ & $5(27.78 \%)$ & 11.68 & 0.0029 \\
\cline { 1 - 3 } $21-30$ & $68(80 \%)$ & $17(20 \%)$ & & \\
\cline { 1 - 3 } & $9(42.86 \%)$ & $12(57.14 \%)$ & & \\
\hline
\end{tabular}

\begin{tabular}{|c|c|c|c|c|}
\hline \multicolumn{5}{|l|}{ Literacy } \\
\hline Literate & $44(60.27 \%)$ & $29(39.73 \%)$ & \multirow[t]{2}{*}{6.07} & \multirow[t]{2}{*}{0.014} \\
\hline Illiterate & 46 (83.84\%) & $9(16.36 \%)$ & & \\
\hline \multicolumn{5}{|l|}{ Diet } \\
\hline Vegetarian & $59(90.77 \%)$ & $6(9.23 \%)$ & \multirow[t]{2}{*}{22.71} & \multirow[t]{2}{*}{$<0.00001$} \\
\hline Non-vegetarian & $31(52.54 \%)$ & $28(47.46 \%)$ & & \\
\hline \multicolumn{5}{|l|}{ Birth interval } \\
\hline$\leq 2$ years & $65(72.22 \%)$ & $25(27.78 \%)$ & \multirow[t]{2}{*}{40.05} & \multirow[t]{2}{*}{$<0.00001$} \\
\hline$>2$ years & $3(8.82 \%)$ & $31(91.18 \%)$ & & \\
\hline
\end{tabular}

\begin{tabular}{|l|l|l|l|l|}
\hline Treatment & $28(82.35 \%)$ & $6(17.65 \%)$ & 0.017 & 0.87 \\
\hline Not taking & $75(75 \%)$ & $25(25 \%)$ & & \\
\hline Taking & $17(18.89 \%)$ & $73(81.11 \%)$ & 16.39 & 0.000052 \\
\cline { 1 - 3 } Awareness of anemia and Antenatal care \\
\cline { 1 - 3 } Aware & $19(55.88 \%)$ & $15(44.12 \%)$ & & \\
\hline Not aware
\end{tabular}

A highly significant association of anemia was found with diet $(x 2=22.71, p<0.05)$ and birth interval $(x 2=40.05, p<0.05)$. other factors associated with anemia were found to be age $(x 2=11.68, p<0.05)$, literacy $(x 2=6.07, p<0.05)$, and awareness of anemia and ANC $(x 2=16.39, p<0.05)$. Treatment history was not significantly associated with anemia $(x 2=0.017, p>0.05)$.

\section{Discussion}

Anemia during pregnancy is a global public health challenge facing the world today, especially in developing countries.

The onset of anemia occurs in childhood, degrades in the adolescence period in girls, and gets intensified during pregnancy. It is the most common nutritional deficiency disorder in the world. When compared with other developing countries, India shows a higher prevalence of anemia in all age groups[7].

In the present study, theprevalence of anemia in pregnant women is found to be $72.58 \%$.Similar findings were reported by Prashant $D$ et.al $(72.75 \%)$ and Nadeem Ahmad et.al(74.80\%)[3,16]. However, studies conducted by Suryanarayana etal, Sharma etal, and Bisoi etal shows the prevalence of anemia $64 \%, 63 \%$, and $67.8 \%$ respectively $[7,23,24]$. Whereas the study conducted by Kaul et.al prevalence of anemia is observed to be very high (91\%) [25]. The mean hemoglobin level in the present study is found to be $9.01 \pm 1.89 \mathrm{gm} / \mathrm{dl}$ comparable findings $(9.77 \pm 0.92 \mathrm{gm} / \mathrm{dl})$ were found in the study conducted by Ashish Bhattacharjee et.al in northeast India [8]. Women belonging to low socioeconomic stratum are deprived of a diet rich in iron and folic acid as well as due to unhygienic conditions they are more prone to infections which causes chronic blood loss. A high prevalence of anemia found in the present study is attribut factors.

It is observed that in the present study the majority $(46.67 \%)$ of the anemic pregnant women belong to the age group 21-25. Kaul et. al in Kashmir valley observed a very high prevalence $(93.67 \%)$ of 
Anemia in a similar age group [25]. A study conducted by Suryanarayana et.al also observed high prevalence(73\%) of anemia in a similar age group[7] and in the study conducted by Sharma et.al in Rajasthan city, only $38 \%$ of women were anemic in similar age group[23].Among the women belonging to low socioeconomic class, food habits during childhood and adolescent age group play a major role; poor Intake of iron-containing food during this age and its poor bioavailability increases the risk of anemia among them. Their early marriage and adolescent pregnancy make them prone to anemia, contributing to the high prevalence of anemia in this age group.

In the present study, the prevalence of moderate anemia is found to be $52.42 \%$ followed by mild anemia $15.32 \%$ and severe anemia $4.84 \%$.This study highlights the high prevalence of moderate anemia and low prevalence of severe anemiasimilar findings can be observed in studies conducted by Suryanarayana et al, Sharma etal and Wadgave HV[7,23,26].Lack of awareness and poor health education results in failure to utilize available medical facilities by low socioeconomic class, as well as other factors like poverty and ignorance contribute to the various degrees of anemia.

In rural India, a blood loss of even $200 \mathrm{~mL}$ in severe anemia will lead to shock and death, indirectly contributing to maternal mortality owing to anemia[7].

In the present study, PBS examination of blood samples highlights the microcytic hypochromic blood picture (74.44\%)as the predominant morphological type of anemia followed by normocytic normochromic(20\%), microcytic normochromic (3.33\%) and normocytic hypochromic $(2.22 \%)$. The study conducted by KanyesigyeHamson MD etal also shows the predominance of microcytic hypochromic picture $(76.7 \%)$ followed by normocytic normochromic anemia (13.5\%),macrocytic hypochromic anemia(8.7\%) and normocytic hypochromic anemia $(1.2 \%)$ [18]. A very high prevalence(93\%) of microcytic hypochromic anemia has been found in a study conducted by Anjali Kiran Bhirudetal [17]. The high percentage of Microcytic hypochromic pictures of PBS is suggestive of the predominance of iron deficiency anemia in pregnant women. Lack of awareness about diet and medication to be taken for prevention of anemia, poor bioavailability of iron,chronic infections, and poverty contribute to the unavailability of wholesome diet to ANC women
All these factors are responsible for various types of anemia among women belonging to the low socioeconomic group.

In the present study, the predominant morphological type is the microcytic hypochromic, mean value of hemoglobin $(9.01 \pm 1.89$ $\mathrm{g} / \mathrm{dl})$, and packed cell volume $(28.17 \pm 3.56 \%)$ is found to be decreased. All blood indices were below normal limits, however, MCV was too low $(71.28 \pm 11.21 \mathrm{fl})$ compared to other indices; suggestive of iron deficiency anemia. The value of RDW-CV found to be $15.46 \pm 3.63 \%$ which is above the normal value. Increased RDW-CV and low MCV in the present study can be due to iron deficiency anemia. A similar study conducted by Jaahnavee Trivedi et al have also concluded that increased RDW-CV with low MCV which confirms iron deficiency anemia[22].

A highly significant association of anemia was found with diet $(x 2=22.71, p<0.05)$ and birth interval $(x 2=40.05, p<0.05)$. These findings correspond to the study conducted by Anjali Kiran Bhirud et.al[17]. Meat, chicken, and fish which are very rich sources of iron are missing in diet due to poverty and lack of knowledge, even a vegetarian diet is rarely wholesome, making dietary deficiencies even worse in the women belonging to low socioeconomic class. Birth interval less than two years depletes the iron stores in the women's body.In the present study, other factors associated with anemia were found to be age $(x 2=11.68$, $\mathrm{p}<0.05)$, literacy $(x 2=6.07, \mathrm{p}<0.05)$ and awareness of anemiaandAntenatal care $(x 2=16.39, p<0.05)$. Similar factors were also noted to be responsible for anemia in the study conducted by Dr. Maya Khandat [19]. Pregnancy at adolescent age, illiteracy, and lack of awareness of anemia in rural pregnant women are predisposing factors for nutritional deficiency and anemia. Treatment history was not significantly associated with anemia $(x 2=0.017, p>0.05)$ in the present study. Instead of the consumption of iron-folic acid tablets, the majority $(75 \%)$ of the women were found to be anemic in the present study. A study conducted by Srilatha J.highlights that, although many control programs for anemia have been implemented for many years, the magnitude of the problem remains the same with no significant changes even after folic acid and iron supplements [13]. The probable reason behind this is; among women belonging to the low socioeconomic group or a rural area there is of lack of awareness of anemia, there is the failure 
To complete prophylactic treatment, there are noncompliance and lack of awareness about repercussions of taking incomplete prophylactic treatment. However, studies conducted by KnyesigyeHamson etal and Yakoob etal shows that the use of hematinicsis protective against anemia in pregnancy, it reduces the risk of developing anemia at term by $73 \%[18,27]$. So proper information, antenatal care, follow up and vigilance on antenatal treatment will improve the maternal and fetal outcome.

\section{Limitations}

This study is conducted only in a single institution. Hence, further studies have to be conducted in different hospitals in rural areas of Maharashtra to have findings representing the whole population and to access the actual extent of the problem and factors associated with it. In addition to these further laboratory investigations like serum iron and serum ferritin should be done so as to guide clinicians to work alleviating the existing problems.

\section{Conclusion}

India became the first developing country to take up a National Nutritional Anemia Prophylaxis Program (NNAPP) to prevent anemia among pregnant women, but these programs are not reaching the rural women upto the expected extent.The high prevalence of anemia in this study is probably related to the low socioeconomic status of the women, which may have an impact on their nutritional status.Microcytic hypochromic blood picture is predominant in the present study, it indicates there are deficient iron intake and lack of awareness about proper diet. Proper interaction, information, medication, proper diet containing all nutrients, cooking in iron utensils, fortification of food and salt with iron and birth control for proper spacing of pregnancies; such measures will go long way in improving maternal and fetal outcome.

\section{What does the study add to the existing knowledge?}

The present study highlights the prevalence of anemia in pregnant women belonging to the low socioeconomic group, the most prevalent morphological type of anemia among this group, and the factors associated with it. So that clinicians can be properly guided for the further management of the problem.

\section{Authors contribution}

Dr. Jayraj Devidas Patil: Sample collection, collection of references, data analysis, statistical analysis, manuscript preparation.

Dr. Mangala Rajesh Nagare: Concept and study design.

\section{Reference}

01. World Health Organization. The prevalence of anemia in women- A tabulation of available information. WHO/MCH/MSM922Geneva. 1992.

Available from: [Article:http://whqlibdoc.who.int] [Crossref]

02. Jufar AH, Zewde T. Prevalence of anemia among pregnantwomen attending antenatal care at TikurAnbessa specialized hospital, AddisAbaba Ethiopia. J Hematol Thromb Dis. 2014;2(1)125. doi: [Article:https://doi.org/10.4172/23298790.1000125][Crossref]

03. Prashant D, Jaideep KC, Girija A, Mallapur MD. Prevalence of anemia among pregnant women attending antenatal clinics in rural field practice area of Jawaharlal Nehru Medical college, Belagavi, Karnataka, India. Int J Community Med Public Health. 2017;4(2)537-41.

doi:[Article:http://dx.doi.org/10.18203/23946040.ijcmph20170287][Crossref]

04. Ngonzi J, Julius M. Prevalence, Morphological Types and Factors Associated With Anemia among Mothers Attending Antenatal Clinic at Mbarara Regional Referral Hospital, South Western Uganda, Prevalence. J Health Med Nur. $2016 ; 25$.

Available

at

[Article:https://iiste.org/Journals/index.php/JHMN/art icle/view/30117][Crossref]

05. Rajamouli J, Ravinder A, Reddy S, Pambi S. Study on Prevalence of Anemia among Pregnant Women attending Antenatal Clinic at Rural Health Training Centre (RHTC) and Chalmeda Anand Rao Institute of Medical Sciences Teaching Hospital, Karimnagar, Telangana, India. Int J Contemp Med Res. 2016;3(8)23882391.

Available at

[Article:https://www.ijcmr.com/uploads/7/7/4/6/774 64738/ijcmr_832_aug_15.pdf][Crossref] 
06. Kalaivani K. Prevalence and consequences of anemia in pregnancy. Indian J Med Res. 2009;130(5)627-633.

[Crossref]

07. Mangla M, Singla D. Prevalence of anemia among pregnant women in rural India: a longitudinal observational study. Int J Reprod Contracept Obstet Gynecol. 2016;5(10)35003505 .

doi: [Article:http://dx.doi.org/10.18203/23201770.ijrcog20163431][Crossref]

08. Suryanarayana R, Santhuram AN, Chandrappa M, Shivajirao P, Rangappa SS. Prevalence of anemia among pregnant women in rural population of Kolar district. Int J Med Sci Public Health. 2016;5(3)454-458.

doi:

[Article:https://doi.org/10.5455/ijmsph.2016.230720 1575][Crossref]

09. Bhattacharjee A, Begum F, Bayan M, Das R. Study of the Prevalence of Anemia among Antenatal Women Visiting a Tertiary Care Hospital- A Report from North-East India. SJAMS. 2017;5(8B)3087-3091.

doi: [Article:https://doi.org/10.21276/sjams] [Crossref]

10. K Park. Park's Textbook of Preventive and Social Medicine, Nutrition and Health. 24th edition M/s Banarsidas Bhanot publishers, Jabalpur. $661,658,679$.

[Crossref]

11. Debalina S,Harshida G,Yash S, Ujjwal S,Harsoda JM. A Screening study on prevalence of anemia in pregnant women during different trimester. Sch J App Med Sci. 2014;2(5B)1639-1642.

[Crossref]

12. Seshadri S. Nutritional anemia in South Asia, In Malnutrition in South Asia-A regional profile Ed, Stuart Gillespie UNICEF. ROSA Publication. 1997; 5;145-159.

[Crossref]

13. Sharma $P$, Mehta S, Nagar R. Prevalence of anemia and sociodemographic factors associated with anemia among pregnant women attending antenatal hospital in Jaipur city India. IOSR J Pharm Biol Sci. 2013;6(3)1-5.

Available

[Article:https://pdfs.semanticscholar.org/81a6/394d5 7782c134aaf9af1694c5fab12b481be.pdf][Crossref]
14. Bangera IS. A study of morphological types of anemia. IJSR. 2017;6(6)1181-1182.

Available from: [Article:https://www.ijsr.net/archive/v6i6/ART201743 80.pdf][Crossref]

15. Srilatha J. Prevalence of anemia in pregnant mothers and their outcome- a study in a semi urban area. Int J Reprod Contracept Obstet Gynecol. 2017;6(11)4886-4889.

doi: [Article:http://dx.doi.org/10.18203/23201770.ijrcog20174994][Crossref]

16. Grewal A. Anemia and pregnancy- Anaesthetic implications. Indian J Anaesth. 2010;54(5)380386.

doi: [Article:https://doi.org/10.4103/00195049.71026][Crossref]

17. Naigamwalla DZ, Webb JA, Giger U. Iron deficiency anemia. Can Veter J. 2012;53(3)250256.

[Crossref]

18. Ahmad N, Kalakoti P, Bano R, Syed MMA. The prevalence of anemia and associated factors in pregnant women in a rural Indian community. AM J. 2010;3(5)276-280.

doi:

[Article:https://doi.org/10.4066/AM].2010.286:276280][Crossref]

19. Bhirud AK, Bhole VD. A study of prevalence of anemia in pregnancy and associated factors at tertiary health care. Int J Gynaecol. 2017;3(3)122-124.

doi: [Article:https://doi.org/10.26611/10123312] [Crossref]

20. Trivedi J, Saiyad S. Study of haematological parameters in anemicpregnant women. Int J Basic Appl Physiol. 2016;5(1)165-167.

[Crossref]

21. Khandat M. Nutritional status of rural pregnant women in Beed district of Maharashtra of India. IPCBEE. 2014;67(18)92-96.

doi: [Article:https://doi.org/10.7763/IPCBEE] [Crossref]

22. Yakoob MY, Bhutta ZA. Effect of routine iron supplementation with or without folic acid on anemia during pregnancy. Biomed central Public Health. $2011 ; 11(3) 1-10$.

doi: [Article:https://doi.org/10.1186/1471-2458-11S3-S21][Crossref] 
23. Wadgave HV. Burden of anemia among the pregnant women in rural area. Healthline. $2011 ; 2(2) 76-77$.

[Crossref]

24. JB Sharma, Shankar M. Anemia in pregnancy. JIMSA. 2010;23(4)253-260.

Available

at [Article:http://medind.nic.in/jav/t10/i4/javt10i4p253. pdf][Crossref]

25. Government of India;162. Central Bureau of Health Intelligence, Directorate General of health Services Ministry of Health and Family Welfare. National Health Profile. 2018, 13th issue.

Available at [Article:https://www.cbhidghs.gov.in] [Crossref]
26. Kaul R, Ahmad J, Baba TA, Sheikh S, Ahmad A, Ashraf $M$. Anemia in pregnant women in a rural block of Kashmir valley- its prevalence and socio-demographic associates. Int J Med Sci Public Health. 2013;2(4)814-818. doi: [Article:https://doi.org/10.5455/ijmsph.2013.130620 131][Crossref]

27. Bisoi S, Haldar D, Majumdar TK, Bhattacharya N, Sarkar GN, Ray SK. Correlates of anemia among pregnant women in a rural area of West Bengal. J Fam Welfare. 2011;57(1)72-78. Available from: [Article:http://medind.nic.in/jah/t11/i1/jaht11i1p72.p df][Crossref] 